\title{
Praksisveiledning i team kan styrke sykepleieres veiledningskompetanse
}

Teambasert veiledning, hvor flere sykepleiere

samarbeider om å veilede studentene i praksis, kan gi bedre kontinuitet i praksisperioden og mer nyanserte vurderinger av studentene.

\section{Therese Antonsen}

Universitetslektor

Institutt for samfunnsmedisin og sykepleie, Fakultet for medisin og helsevitenskap, Norges teknisk-naturvitenskapelige universitet

\section{Bente Paulsen}

Universitetslektor

Institutt for samfunnsmedisin og sykepleie, Fakultet for medisin og helsevitenskap, Norges teknisk-naturvitenskapelige universitet

\section{Astrid Bjørnerheim Hynne}

\section{Førstelektor}

Institutt for samfunnsmedisin og sykepleie, Fakultet for medisin og helsevitenskap, Norges teknisk-naturvitenskapelige universitet

Sykepleierstudent

Praksisveiledning 
Sykepleiere har en viktig funksjon som veiledere for studenter i klinisk praksis. A utvikle en modell for veiledning som kan styrke sykepleieres kompetanse som veiledere, var sentralt i prosjektet vi presenterer i denne artikkelen. Funnene fra prosjektet kan tyde på at veiledningsteam med hovedveileder er en modell som kan styrke kontinuiteten i og samarbeidet om veiledningen av sykepleierstudenter i praksis.

Tilnærmet halvparten av bachelorutdanningen i sykepleie i Norge foregår i klinisk praksis, og praksis blir dermed en viktig læringsarena. Sykepleiere ved praksisstedet har ansvaret for den daglige veiledningen av studenter og er viktige for å skape et godt læringsmiljø (1).

Veiledere har en dobbeltrolle: De skal både veilede og vurdere studentene (2). Relasjonen mellom veileder og student kan være med på å påvirke læringsutbyttet fra praksis på både en positiv og en negativ måte (2).

Ifølge Nokut - Nasjonalt organ for kvalitet i utdanningen - har også organiseringen av praksis betydning for læringsutbyttet (3). Praksisstudiene skal utformes slik at de sikrer at læringsutbyttene oppnås (4).

\section{Hovedveiledermodellen var utgangspunktet}

Høsten 2016 ble det igangsatt et prosjekt med samarbeidsstillinger mellom St. Olavs hospital og Fakultet for medisin og helsevitenskap ved NTNU. Prosjektet ble delt opp i ulike delprosjekter.

Vårt delprosjekt ble kalt «Hovedveiledermodellen med veilederteam og studentstyrt læring i praksis» (se figur 1 under) og ble knyttet opp mot en av sengepostene på kirurgisk klinikk, før det ble implementert på tre andre sengeposter. En sykepleier ved kirurgisk klinikk og en lektor ved NTNU hadde begge en 20-prosentstilling til å drive prosjektet.

\section{«Et mål var at veilederne i større grad skulle samarbeide om studentveiledningen.»}


Veilederteamet i prosjektet var organisert slik at det var like mange sykepleiere som studenter (opptil fireseks studenter). En av sykepleierne i veilederteamet ble tildelt hovedveilederansvaret. Hovedveilederen deltok på alle formelle møter med sykepleierstudentene og praksislæreren: praksisavtale, midt- og sluttvurdering samt skriving av vurderingsdokument.

Studentenes turnus ble utformet av praksisfeltet. I de første ukene av turnusen ble det lagt opp til en-til-enoppfølging med samme veileder for å ivareta kontinuitet og trygghet (5). Etter dette rullerte studentene mellom veilederne i veilederteamet.

\section{Alle inngikk i felles praksisavtale}

Et mål var at studentene skulle utvikle sin evne til kritisk tenkning og klinisk resonnering i møte med flere veiledere i ulike veiledningssituasjoner. Et annet mål var at veilederne i større grad skulle samarbeide om studentveiledningen. Hensikten med prosjektet var å utvikle veilederteam med hovedveileder for å styrke veilednings- og vurderingskompetansen.

Det ble utformet en felles praksisavtale med alle studentene på en sengepost for å skape en felles diskusjon om hvordan læringsutbyttene kunne bli oppnådd i løpet av praksisperioden. Det ble satt av rundt ti minutter til hver student alene for å vise frem tidligere vurderingsdokumenter og for eventuelt å diskutere individuelle læringsbehov.

For å sikre kontinuitet, progresjon og et godt veilednings- og vurderingsgrunnlag ble det utviklet sjekkliste og loggbok med en mal for refleksjon over praksisdagen (se tabell 1 under). Både studenter og veiledere skulle skrive etter denne malen daglig. Veiledningsheftet til veilederne ble utformet med utgangspunkt i et eksisterende veiledningshefte. 


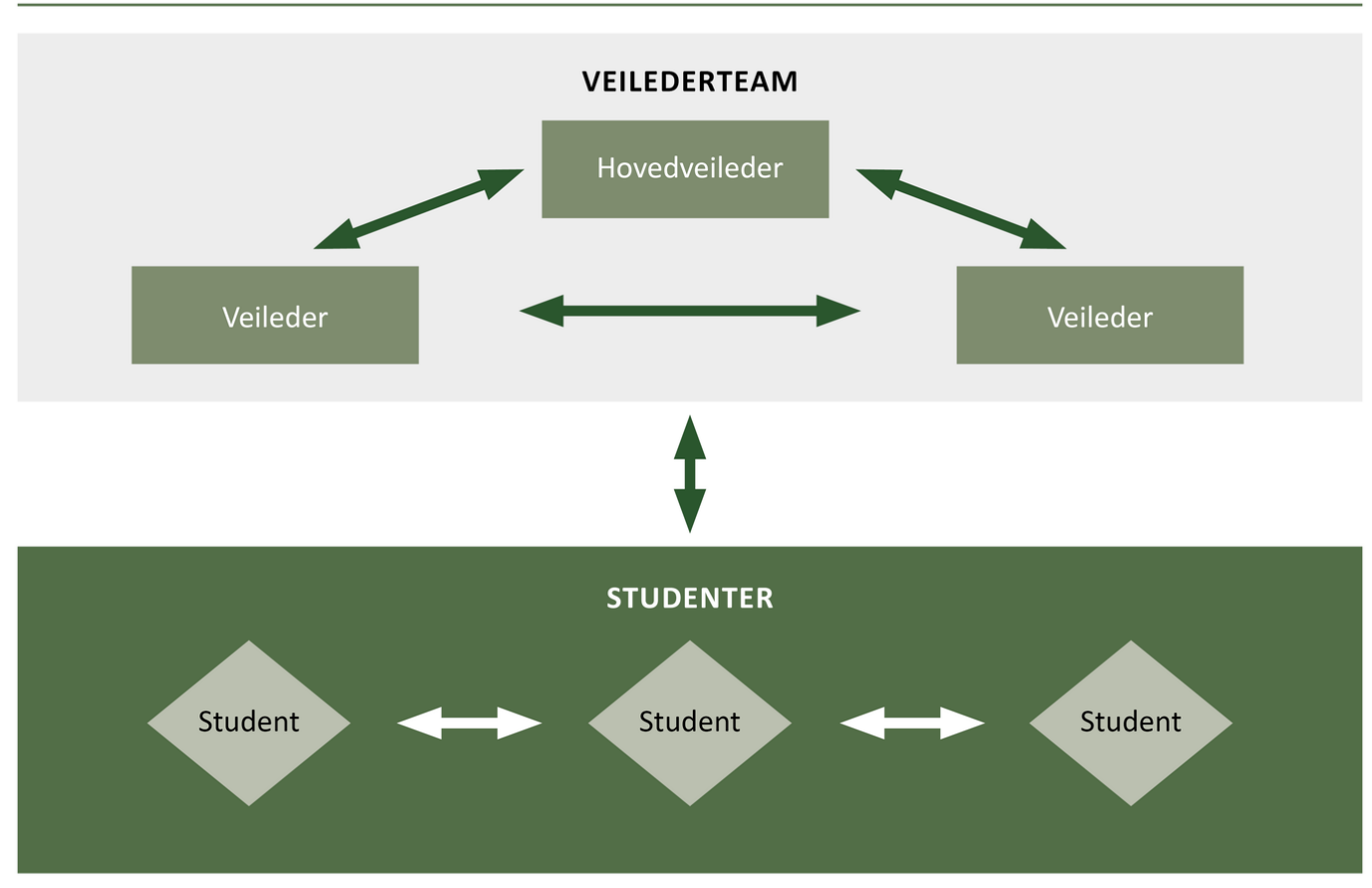

Figuren viser et veilederteam bestående av en hovedveileder og to veiledere. Hovedveilederen har det overordnede ansvaret. Hele veilederteamet har ansvar for oppfølging, veiledning og vurdering av studentene.

Tabell 1. Ansvarsfordeling

\begin{tabular}{|c|c|c|}
\hline Hovedveileder & Veiledere & Studenter \\
\hline $\begin{array}{l}\text { - delta på alle formelle møter } \\
\text { med utdanningsinstitusjonen } \\
\text { (forventningssamtale/målsamtale, } \\
\text { midt- og sluttvurdering) } \\
\text { - være kontaktperson mot } \\
\text { utdanningsinstitusjonen } \\
\text { - skrive vurderingsdokumenter ut } \\
\text { fra loggbøker og tilbakemeldinger } \\
\text { fra veilederteamet } \\
\text { - delta i den daglige veiledningen } \\
\text { av sykepleierstudentene } \\
\text { - skrive loggbok } \\
\text { - følge opp sjekklister }\end{array}$ & $\begin{array}{l}\text { - ta del i den daglige veiledningen } \\
\text { av sykepleierstudentene } \\
\text { - bidra i vurderingen av den } \\
\text { enkelte student } \\
\text { - skrive loggbok } \\
\text { - følge opp sjekklister }\end{array}$ & $\begin{array}{l}\text { - } \text { skrive loggbok } \\
\text { gi veilederne oversikt } \\
\text { over hvilke læringsmål de } \\
\text { ønsker å oppnå i løpet av } \\
\text { vakten } \\
\text { - følge opp sjekklister }\end{array}$ \\
\hline
\end{tabular}

Tabellen viser ansvarsfordelingen mellom hovedveileder, veiledere og studenter.

\section{Metode}

Evalueringen av prosjektet ble gjennomført med spørreskjema til veiledere, studenter og ledere. I denne artikkelen blir svarene fra veiledere og studenter analysert og diskutert.

Sykepleierstudentene som deltok i prosjektet, hadde andre og tredje studieårs kirurgiske praksis på de utvalgte prosjektavdelingene. Utvalget av veiledere var deltakere i det enkelte veilederteamet. 
Spørreskjemaet som ble utviklet til studentene, var inspirert av spørsmålsstillinger i den norske versjonen av The Clinical Learning Environment, Supervision and Nurse Teacher Scale, CLES+T (6). I tillegg ble det stilt spørsmål knyttet til forberedelser i forkant av praksisperioden og til vurdering av hovedveiledermodellen. Spørreskjemaet ble delt ut til studentene den siste uken av praksisperioden.

Spørreskjemaet til hovedveilederne og veilederne var inspirert av spørreskjemaet CLES+T og ble utdelt etter hvert semester (etter to praksisperioder).

Svaralternativene i spørreskjemaene var «helt uenig», «delvis uenig», «verken enig eller uenig», «delvis enig» og «helt enig». I skjemaene var det også åpne kommentarfelt.

I analysen av svarene på spørreskjemaene brukte vi det statistiske programmet SPSS versjon 25 for behandling av tallmaterialet med beskrivende statistikk i form av frekvensanalyser. Åpne spørsmål ble brukt til å underbygge svarene.

Studentene fikk muntlig og skriftlig informasjon om prosjektet før de startet i praksis. Det var frivillig å besvare spørreskjemaet for både studenter og veiledere. Spørreskjemaet var anonymt.

Vi brukte Norsk senter for forskningsdata (NSD) sin sjekkliste for personopplysningsregisteret og fant ut at det ikke var nødvendig å melde prosjektet til NSD, da vi ikke brukte personopplysninger.

\section{Resultater}

Det var 58 studenter som fikk spørreskjemaet, og 47 svarte (81 prosent). Av disse var 30 studenter fra andre studieår og 17 fra tredje studieår. 
Fra veilederne fikk vi inn 19 spørreskjemaer. Mange av veilederne var veiledere over flere praksisperioder. Det totale antallet hovedveiledere og deltakere $\mathrm{i}$ veilederteam ble ikke registrert. Fra hovedveilederne var det 8 skjemaer, og resten av skjemaene var fra veiledere i veilederteamene.

Veilederne hadde jobbet som sykepleiere fra et halvt til trettiåtte år. Halvparten hadde jobbet som sykepleiere i færre enn fem år. De fleste av veilederne hadde vært veiledere for flere enn tre studenter før prosjektet, mens det var fire av dem som ikke hadde vært veiledere tidligere.

\section{Veiledningsforholdet var preget av tillit}

De fleste av studentene (39 av 46) opplevde at de fikk kontinuerlig tilbakemelding fra hovedveilederen og veilederteamet. Studentene oppga at veiledningsforholdet var preget av tillit (43 av 46), et likeverdig forhold som fremmet læring (40 av 46), og gjensidig interaksjon (42 av 46).

Alle veilederne svarte at de ga kontinuerlig tilbakemelding til studentene, og at forholdet mellom praksisveiledere og studenter fungerte godt og var preget av tillit.

\section{«Nærmere halvparten av studentene var delvis eller helt enige $i$ at de ikke savnet en fast praksisveileder.»}

De fleste av studentene (33 av 46) opplevde at det var positivt for deres læringsprosess at avdelingen hadde veilederteam bestående av flere praksisveiledere og en hovedveileder, mens 6 studenter oppga at de var helt uenige eller delvis uenige i dette.

Nærmere halvparten av studentene ( 20 av 45) var delvis eller helt enige $i$ at de ikke savnet en fast praksisveileder, mens 15 av studentene var helt eller delvis uenige i dette. På dette punktet var det noe forskjell i svarene fra de enkelte avdelingene. 
På spørsmål om «hovedveileder og veilederteamet utfylte hverandre slik at jeg som student følte meg godt ivaretatt», var 37 av studentene helt eller delvis enige.

\section{Modellen styrket praksisens relevans}

Flertallet av veilederne ( 7 av 11) og hovedveiledere (6 av 8) mente at denne modellen bidro til å styrke praksisstudienes kvalitet og relevans for studentene. Alle hovedveilederne mente at praksismodellen fungerte godt på sin avdeling.

Ifølge hovedveilederne førte modellen til $\varnothing \mathrm{kt}$ bevissthet om betydningen av god studentveiledning. Dette ble st $\varnothing t t e t$ av veilederne i veilederteamet. Flertallet av veilederne opplevde at hovedveilederen støttet dem i sin veilederfunksjon (7 av 12). En veileder uttalte:

«Godt å være i et team med andre praksisveiledere og hovedveileder.»

\section{«Nesten alle i veilederteamene ønsket mer kompetanse innen veiledning.»}

Hovedveilederen skrev alle vurderingsdokumenter til studentene. Seks av åtte hovedveiledere opplevde at dette fungerte godt. Det var noe mer spredning $\mathrm{i}$ veiledernes svar på dette punktet, der seks var delvis eller helt enige, tre var verken enige eller uenige, og en var delvis uenig $(\mathrm{n}=11)$.

En utfordring for hovedveilederne var at loggb $\varnothing$ kene ble fulgt dårlig opp fra de andre i veilederteamet. En av hovedveilederne uttalte:

«Det gikk helt fint å skrive alle vurderingene selv på grunn av muntlig tilbakemelding fra veilederteamet.» 
Flere kommenterte at det hadde vært lærerikt å være hovedveileder, og de ønsket å få avsatt mer tid til forberedelser. Ingen av veilederne hadde formell veiledningskompetanse, men nesten alle (14 av 19) i veilederteamene $\varnothing$ nsket mer kompetanse innen veiledning.

\section{Sykepleierne var motivert til å veilede}

Flertallet (18 av 19) av veilederne oppga at det ble laget en plan for studentenes praksisperiode, med turnus, rotasjon mellom veilederne i veilederteamet og rotasjonsplan/hospitering. Det var bare 5 av 19 som hadde fătt avsatt tid til forberedelser før studentene kom, med noe variasjon mellom avdelingene.

I veilederteamet opplevde 15 av 19 at de var godt forberedt på mottak av studentene. Motivasjonen for å veilede studentene var stor (16 av 19). Halvparten av veilederne svarte likevel at de ikke var kjent med hvilken teoretisk og praktisk undervisning studentene hadde hatt.

Det var bare 7 av 19 veiledere som var kjent med studentenes læringsutbyttebeskrivelser.

Studentveiledningen ble sett på som en viktig oppgave (17 av 19). Alle mente at avdelingene la til rette for læresituasjoner i praksis, og et stort flertall var enige om at kollegaer og veiledere samarbeidet godt om studentenes læring (16 av 19).

\section{Kontinuitet er en nøkkelfaktor}

Flertallet av veilederne i vårt prosjekt mente at hovedveiledermodellen bidro til å styrke praksisstedets kvalitet og relevans for studentene. Veilederne opplevde $\varnothing \mathrm{kt}$ bevissthet på viktigheten av god veiledning.

\section{«Flertallet av veilederne opplevde at hovedveilederne støttet dem i deres veilederfunksjon.»}


Gjennom veiledningsteamet hadde alle felles ansvar for den daglige veiledningen. Veiledere kan oppleve det som utfordrende å være alene i veilednings- og vurderingssituasjoner (7). Vår unders $\varnothing$ kelse viser at flertallet av veilederne opplevde at hovedveilederne støttet dem i deres veilederfunksjon. De fleste av studentene opplevde at det var positivt for deres læringsprosess at avdelingen hadde veilederteam med en hovedveileder.

Flere var hovedveiledere over flere praksisperioder. Det skapte kontinuitet, de fikk mengdetrening i å veilede og vurdere studenter, og de fikk trygghet i sin rolle som hovedveileder. Ifølge Nokut (3) er nøkkelfaktoren for å sikre kvalitet i praksisveiledningen at praksisveiledere har faglig kompetanse og veiledningskompetanse, og at det er kontinuitet i praksisveiledningen.

Hovedveilederen er kontaktpersonen mot praksislæreren og utdanningsinstitusjonen. På den ene siden kan det være enklere for praksislærerne å ha oversikt over hvem de skal kontakte i praksis. På den andre siden kan det føre til at det blir vanskeligere for de andre i veilederteamet å ta kontakt med praksislærerne. Fra praksislærernes side kan de miste oversikten over veilederne som følger studentene.

\section{Veiledere ønsker å gi balansert vurdering}

I vårt prosjekt skrev hovedveilederne

vurderingsdokumentene ut fra loggb $\varnothing$ ker og tilbakemeldinger fra veilederteamene. Flertallet av hovedveiledere opplevde at dette fungerte godt.

Veiledere er opptatt av å gi studentene en balansert vurdering (8). Flere sykepleieres vurderinger kan gi en mer nyansert vurdering enn bare én sykepleiers subjektive mening. Relasjonen mellom student og veileder kan også påvirke vurderingen og tilbakemeldingen til studenten (2), noe som kan forebygges ved at studentene blir vurdert av et helt team. 


\section{«Det kan oppleves som negativt hvis studentens selvvurdering er annerledes enn veiledningsteamets.»}

Når hovedveilederen skriver vurderingsdokumentene, kan noen veiledere på den ene siden oppleve at de mister oversikten, noe som kan forsterkes av at de heller ikke er med på vurderingssamtalene.

På den andre siden kan det å slippe å skrive vurderingsdokumenter være en lettelse. Det kan oppleves som krevende å gjøre dette alene, noe tidligere studier har vist (7). De hovedveilederne som hadde rollen over flere perioder, ble også godt kjent med vurderingsdokumentene som skal fylles ut.

Fra studentenes side kan også en felles vurdering fra et veilederteam gi en ubalanse i veiledningsforholdet. Det kan oppleves som negativt hvis studentens selvvurdering er annerledes enn veiledningsteamets. Veiledere kan på sin side bli tryggere på at de gir riktige vurderinger når flere mener det samme.

\section{Det er viktig at flere ser studenten}

Erfaringer fra Henriksen (9) viser at det er svært viktig at flere veiledere ser studenten. Oppstår det utfordringer i praksis, er det flere som kan bidra til å vurdere og løse situasjonen.

Har man en veiledningsmodell der man har samme veileder gjennom hele praksisperioden, er det sårbart dersom veiledningsforholdet ikke fungerer optimalt (2). På den andre siden kan det oppleves som trygt å gå sammen med den samme veilederen en hel periode om relasjonen fungerer. 
Trygghet er viktig, og derfor har vi i prosjektet lagt opp til én veileder per student de to første ukene. Samtidig har studentene i dette prosjektet opplevd at hovedveileder og veilederteam utfylte hverandre, og at veiledningsforholdet var preget av tillit og gjensidig interaksjon. Dette kan tyde på at kontinuerlig veiledning og tilbakemeldinger er ivaretatt, noe som blir sett på som betydningsfullt for læring (3).

\section{Læringsutbyttene bør være kjent}

Veilederne oppga at de var godt forberedt til studentene skulle komme til avdelingen. Dette kan komme av at flertallet av veilederne hadde gjort seg kjent med planen for studentenes praksisperiode. Men mange av veilederne var ikke kjent med studentenes læringsutbyttebeskrivelser.

I forskrift om nasjonal retningslinje for sykepleierutdanning (4) er det uttalt følgende:

«Praksisstudiene skal utformes slik at de sikrer at læringsutbyttet oppnås.» Dette blir vanskelig å oppnå om ikke veilederne kjenner til læringsutbyttebeskrivelsene til studentene.

Samtidig er det viktig for å få en god og individuell veiledning at veilederne har kunnskap om studentens ståsted og læreforutsetninger (10). Det at hovedveileder har ansvaret for de formelle møtene og å utarbeide vurderingsdokumentene kan føre til at de andre veilederne ikke engasjerer seg i samme grad i aktuelle læringsutbytter for praksisperioden.

Ifølge Nokut (3) er kjennskap til læringsutbyttene en viktig forutsetning for både organisering og læring i praksis.

Det at noen av veilederne ikke hadde kjennskap til læringsutbyttebeskrivelsene i vår unders $\varnothing$ kelse, kan også komme av at mange veiledere opplevde at de ikke fikk avsatt nok tid til å forberede studentveiledningen. Det kan også være at begrepet «læringsutbytte» er et utydelig og tvetydig begrep, som både dreier seg om en intensjon og et resultat, slik Opdal (11) hevder. 
Ekman og medarbeidere (12) fant også at studenter opplevde at veiledere ikke hadde satt seg inn i emneplaner og annen informasjon fra utdanningen. Sykepleierstudenter $\varnothing$ nsker veiledere som har forberedt seg (12).

\section{Konklusjon}

Resultatene fra prosjektet kan tyde på at veiledningsteam med hovedveileder er en modell som kan videreføres for å styrke kontinuiteten i og samarbeidet om veiledningen av sykepleierstudenter i praksis.

Resultatene viser også at det i større grad må legges til rette for at veiledere i teamet er kjent med studentenes forkunnskaper og læringsutbyttebeskrivelser for det aktuelle praksisstedet for å ivareta kvaliteten i vurderingen og veiledningen i praksisstudiene.

\section{Referanser}

1. Skaalvik MW. Bedre kvalitetssikring av praksis. Sykepleien. 2015;4:58-61. Tilgjengelig fra: https://sykepleien.no/forskning/2015/o3/evaluering-avklinisk-laeringsmiljo (nedlastet 24.02.2021).

2. Haugan G, Aigeltinger E, Sørlie V. Relasjonen til veilederen betyr mye for sykepleierstudenter i sykehuspraksis. Sykepleien Forskning. 2012;2(7):152-8. Tilgjengelig fra: https://sykepleien.no/forskning/2012/06/relasjonen-tilveileder-betyr-mye-sykepleierstudenter-isykehuspraksis (nedlastet 24.02.2021).

3. Lid SE, Stolinski HS, Kvernenes MS. Hva har NOKUT sagt om kvalitet i praksis? En sammenstilling av informasjon fra NOKUTs tilsynsprosesser. Del av prosjektet Operasjon praksis 2018-2020. Lysaker: Nokut; 2019. Rapport 4-2019.

4. Forskrift 15. mars 2019 nr. 412 om nasjonal retningslinje for sykepleierutdanning. Tilgjengelig fra: https://lovdata.no/dokument/SF/forskrift/2019-03-15$\underline{412}$ (nedlastet 28.01.2021). 
5. Holmsen TL. Hva påvirker

sykepleierstudentenes trygghet og læring i klinisk praksis? Vård i Norden. 2010;30(1):24-8.

6. Henriksen N, Normann HK, Skaalvik MW. Development and testing of the Norwegian version of the Clinical Learning Environment, Supervision and Nurse Teacher (CLES+T) evaluation scale. Int J Nurs Educ Scholarsh. 2012;9(1):1-16.

7. Aigeltinger E, Haugan G, Sørlie V. Utfordringer med å veilede sykepleierstudenter i praksisstudier. Sykepleien Forskning. 2012;2(7):160-6. Tilgjengelig fra: https://sykepleien.no/forskning/2012/o6/utfordringermed-veilede-sykepleierstudenter-i-praksisstudier (nedlastet 24.02.2021).

8. Fillingsnes AB, Thylén I. Praksissykepleieres pedagogiske utfordringer i klinisk veiledning av sykepleierstudenter. Nordisk sygeplejeforskning. 2012;2:249-62.

9. Henriksen J, Espeland K, Blasko E. Koordinerende praksisveileder på sykehus gir mer forn øyde studenter. Sykepleien. 2018. Tilgjengelig fra: https://sykepleien.no/forskning/2018/03/koordinerende -praksisveileder-pa-sykehus-gir-mer-fornoydestudenter (nedlastet 28.01.2021).

10. Bjerknes MS, Christiansen B, red. Praksisveiledning med sykepleierstudenter. Oslo: Gyldendal Akademisk; 2015.

11. Opdal PA. Språk på tomgang? Om «læringsutbytte» i norsk høyere utdanning. Uniped. 2018;41(2):87-105. 
12. Ekman S, Fladeby N, Johansen I, Hardelan C,

Leonardsen A-CL. Hvordan kan sykepleierstudenter få det bedre når de er i praksis? Sykepleien Forskning. 2019. Tilgjengelig fra:

https://sykepleien.no/forskning/2019/o1/hvordan-kan-

sykepleierstudenter-fa-det-bedre-nar-de-er-i-praksis

(nedlastet 28.01.2021). 